\title{
PENINGKATAN KEMAMPUAN PEMECAHAN MASALAH FISIKA DENGAN MODEL PEMBELAJARAN PROBLEM BASED LEARNING
}

\author{
Noor Emmy Ekawati \\ MTs Negeri Magelang \\ ${ }^{1,2} \mathrm{Jl}$. Duku 1 Perumahan Korpri Kramat Magelang \\ E-mail: nooremmy_e1@ymail.com
}

\begin{abstract}
Abstrak - Penelitian ini bertujuan untuk meningkatkan kemampuan pemecahan masalah fisika melalui model pembelajaran PBL kelas IX-G MTs Negeri Magelang. Siswa di kelas IX-G masih belum bisa memecahkan suatu masalah fisika secara sistematis, mereka belajar dengan hafalan, sehingga menyebabkan kemampuan pemecahan masalah masih rendah. Oleh karena itu diperlukan suatu model pembelajaran yang dapat membanngkitkan siswa dalam mengatasi suatu masalah, yaitu dengan model Problem Based Learning (PBL). Pembelajaran Problem Based Learning merupakan pembelajaran yang diperoleh melalui proses menuju pemahaman akan resolusi suatu masalah. Subjek dalam penelitian ini adalah siswa kelas IX-G MTs Negeri Magelang semester gasal tahun ajaran 2016/2017 yang berjumlah 36 siswa. Bentuk penelitian ini adalah penelitian tindakan kelas (PTK) sebanyak dua siklus. Tiap siklus terdiri dari 4 tahapan yaitu perencanaan, pelaksanaan tindakan, observasi, dan refleksi. Instrumen penelitian yang digunakan yaitu lembar perangkat pembelajaran, lembar tes evaluasi, dan lembar observasi. Teknik pengumpulan data yang digunakan adalah observasi dan tes. Analisis data yang digunakan dengan analisis deskriptif. Berdasarkan hasil dan pembahasan pada penelitian tindakan kelas (PTK) yang telah diuraikan, maka dapat diperoleh kesimpulan bahwa model pembelajaran PBL dapat meningkatkan kemampuan pemecahan masalah kelistrikan pada siswa kelas IX-G MTs Negeri Magelang. Hal tersebut dibuktikan dengan persentase ketuntasan belajar siswa yaitu sebelum diberi tindakan ke siklus 1 terjadi peningkatan 28\%, peningkatan dari siklus I ke siklus II sebesar 34\%, dan peningkatan dari pra siklus sampai ke siklus II sebesar $62 \%$.
\end{abstract}

Kata Kunci: fisika, kemampuan pemecahan masalah, problem based learning

\begin{abstract}
This research aims to enhance the problem solving physics through PBL learning model class IX-G MTs Magelang. Students in classes IX-G still could not solve a physics problem systematically, they learn by rote, thus causing problem-solving ability is still low. Therefore we need a learning model that can membanngkitkan students in overcoming a problem, namely the model of Problem Based Learning (PBL). Learning Problem Based Learning is learning gained through the process towards understanding the resolution of a problem. Subjects in this study were students of class IX-G MTs Magelang odd semester of 2016/2017 academic year the 36 students. Forms of this research is classroom action research as much as two cycles. Each cycle consists of four phases: planning, action, observation, and reflection. The research instrument used is sheet learning device, a test sheet evaluation and observation sheet. Data collection techniques used were observation and tests. Analysis of the data used by the descriptive analysis. Based on the results and discussion on classroom action research, which have been described, it can be concluded that the PBL learning model can improve the ability of solving electricity problems in class IX-G MTs Magelang. This is evidenced by the percentage of students learning completeness that before being action to cycle 1 increased 28\%, an increase from the first cycle to the second cycle by $34 \%$, and an increase of precycle to the second cycle by $62 \%$.
\end{abstract}

Keywords: physics, problem solving, problem based learning 


\section{Pendahuluan}

Proses pembelajaran IPA menekankan pada pemberian pengalaman langsung untuk mengembangkan kompetensi agar menjelajahi dan memahami alam sekitar secara ilmiah dan dilaksanakan secara inkuiri ilmiah (scientific inquiry) untuk menumbuhkan kemampuan pemahaman konsep, bekerja dan bersikap ilmiah serta mengkomunikasikannya sebagai aspek penting kecakapan hidup. Dengan kemampuan pemahaman konsep, siswa dilatih untuk mampu menghubungkan kognitif dengan dunia luar sehingga mampu membuat keputusan, pertimbangan, tindakan dan keyakinan secara sederhana.

MTs Negeri Magelang merupakan sekolah yang berlokasi di kota Magelang yang memiliki nilai input siswa yang bagus. Pembelajaran yang dilakukan oleh guru di MTs N Magelang mayoritas masih menggunakan model konvensional yaitu dengan metode ceramah dan diskusi. Nilai ulangan siswa masih ada yang mendapat nilai bagus, hanya saja kemampuan pemecahan masalah siswa terhadap suatu masalah belum dapat dikuasai. Siswa hanya menghafal konsep IPA saja, sehingga apabila ada masalah mengenai konsep IPA yang harus dipecahkan sesuai logika siswa tidak bisa menjawab dan tidak mengatasinya. Jika hanya menghafal konsep maka siswa akan cepat lupa pada materi.

Dengan demikian dalam mempelajari fisika tidak hanya dibutuhkan kemampuan memahami, namun juga dibutuhkan kemampuan untuk mengamati, mengukur, maupun menganalisis hukum-hukum fisika. Pada kenyataannya kemampuan untuk menganalisis sesuatu materi fisika tidak semudah hanya memahaminya saja. Siswa cenderung mengalami kesulitan dalam menguraikan sesuatu materi fisika yang disebabkan oleh kurangnya kemampuan siswa dalam menganalisis rumus maupun hukum fisika. Kebanyakan dari siswa yang telah mampu memahami materi yang diterangkan guru, akan mengalami kesulitan jika diberikan soal yang berbeda dengan contoh soal yang sudah ada. Anggapan sulit yang tertanam pada siswa akan mengakibatkan sikap malas siswa untuk mempelajari fisika lebih mendalam. Dengan demikian guru sebaiknya membiasakan diri untuk senantiasa melatih siswa dalam menganalisis suatu permasalahan fisika.

Kemampuan pemecahan masalah sangat penting bagi siswa, karena dengan memecahkan masalah siswa dapat memahami konsep dan menganalisis secara sistematis. Branca (dalam Sumarmo, 1994) mengatakan bahwa pemecahan masalah dapat diartikan dengan menggunakan interpretasi umum, yaitu pemecahan masalah sebagai tujuan, pemecahan masalah sebagai proses, dan pemecahan masalah sebagai keterampilan dasar.

Sesuai dengan pendekatan yang digunakan dalam Kurikulum 2013, siswa diberanikan untuk mencari sumber belajar lain yang tersedia dan terbentang luas di sekitarnya. Peran guru sangat penting untuk meningkatkan dan menyesuaikan daya serap siswa dengan ketersediaan kegiatan pada buku ini. Guru dapat memperkayanya dengan kreasi dalam bentuk kegiatan-kegiatan 
lain yang sesuai dan relevan yang bersumber dari lingkungan sosial dan alam.

Materi listrik dinamis merupakan salah satu materi yang tingkat penguasaan konsepnya perlu ditelaah lebih lanjut. Siswa tidak bisa menghafal materi saja, atau bahkan menghafal rumus tanpa bisa mengaplikasikannya. Disini siswa dituntut untuk lebih mengupas masalah yang ada dalam pembahasan listrrik.

Untuk mengatasi masalah tersebut maka solusi yang tepat yaitu merubah model pembelajaran di kelas harus ada konsekuensi atau perubahan yang mempengaruhi siswa menjadi kritis, paham konsep, dan mampu memecahkan masalah fisika. Salah satunya yaitu dengan model pembelajaran Problem based Learning (PBL). Pembelajaran berbasis masalah atau yang biasa dikenal dengan PBL merupakan suatu model pembelajaran yang menantang siswa untuk belajar bagaimana belajar, bekerja secara berkelompok untuk mencari solusi dari permasalahan dunia nyata (Medriati, 2013:133).

Pada pembelajaran berbasis masalah siswa diharapkan mampu memiliki beberapa kompetensi yaitu meneliti, mengemukakan pendapat, menerapkan pengetahuan sebelumnya, memunculkan ide-ide, membuat keputusan, mengorganisasi ide, membuat hubunganhubungan, menghubungkan wilayah-wilayah interaksi, dan mengapresiasi kebudayaan (Huda, 2015:257)
Tujuan penelitian ini adalah mengetahui peningkatan kemampuan pemecahan masalah dengan model pembelajaran PBL pada siswa kelas IX MTs N Magelang.

\section{Metode Penelitian}

Penelitian dilakukan di MTs Negeri Magelang pada Semester Gasal tahun ajaran 2016 / 2017. Penelitian dilaksanakan pada bulan September - November 2016. Subjek dalam penelitian ini adalah siswa kelas IX-G MTs Negeri Magelang semester gasal tahun ajaran 2016/2017 yang berjumlah 36 siswa, yang terdiri dari 20 siswa laki-laki dan 16 siswa perempuan.

Metode yang digunakan dalam penelitian ini adalah Penelitian Tindakan Kelas (PTK). PTK adalah penelitian tindakan yang dilaksanakan di dalam kelas ketika pembelajaran berlangsung (Warso, 2013:3). Metode Penelitian Tindakan Kelas sebagai salah satu inovasi pembelajaran yang diharapkan dapat memperbaiki dan maningkatkan praktik pembelajaran di kelas secara berkesinambungan dengan memperhatikan perkembangan pemahaman siswa. Setiap siklusnya terdiri dari empat tahap yaitu perencanaan, tindakan, pengamatan dan refleksi. Prosedur pelaksanaan PTK ini dapat digambarkan sebagai berikut: 


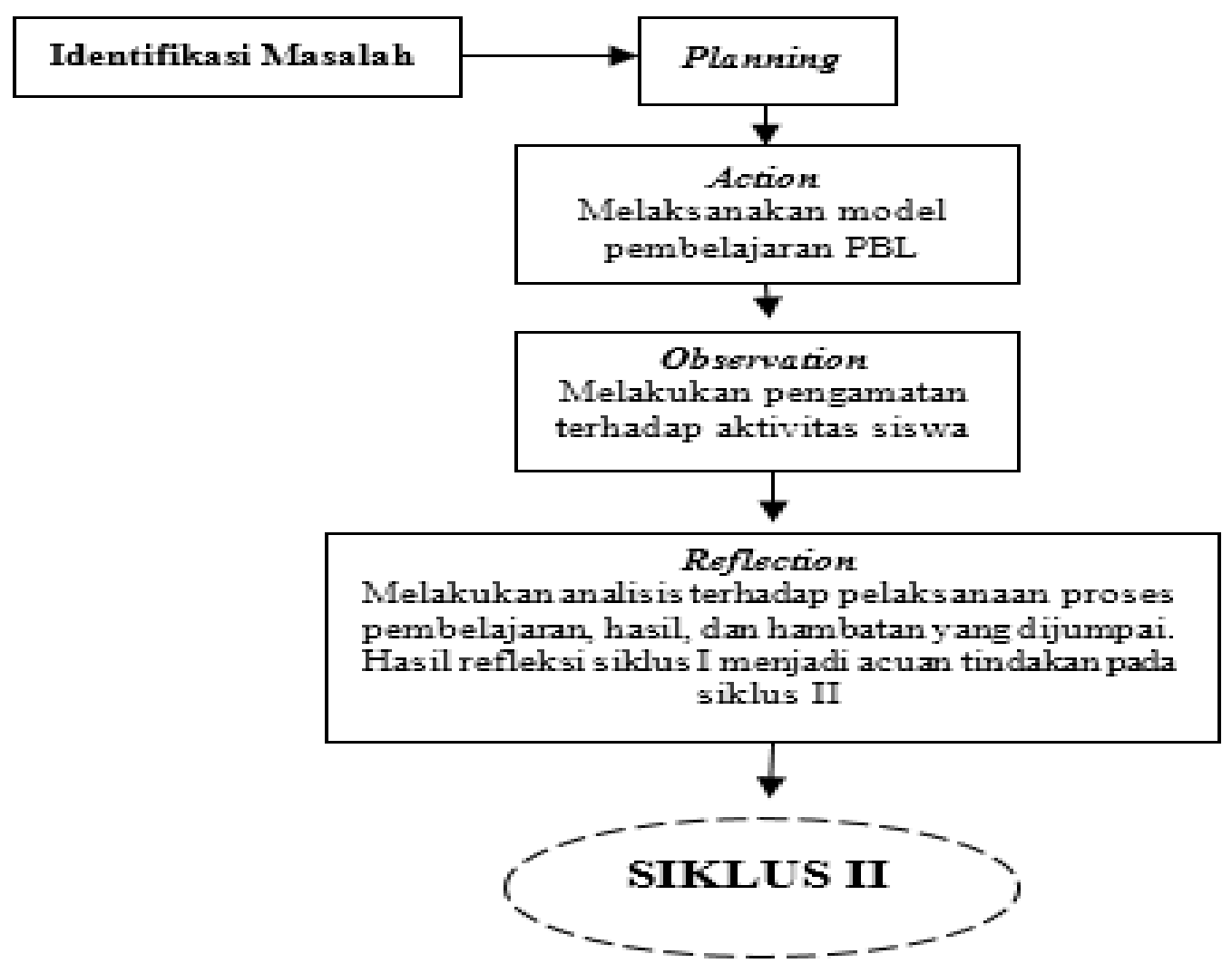

Gambar 1. Prosedur Penelitian PTK

Instrumen yang digunakan dalam penelitian ini yaitu lembar perangkat pembelajaran (berupa silabus, RPP, dan LKS), lembar observasi pelaksanaan pembelajaran berisi lembar aktivitas siswa dan guru, serta lembar evaluasi (postest).

Teknik pengumpulan data dalam penelitian ini adalah metode tes dan metode observasi. Metode tes yang digunakan untuk mengetahui kemampuan pemecahan masalah fisika siswa setelah pembelajaran dengan model PBL adalah tes tertulis, sedangkan bentuk tes yang digunakan adalah soal pilihan ganda. Sedangkan observasi adalah pengamatan yang dilakukan secara langsung oleh peneliti yang meliputi kegiatan pemusatan perhatian terhadap sesuatu objek dengan menggunakan seluruh indera (Arikunto, 2006:89). Metode observasi dalam penelitian ini adalah pengamatan langsung pada saat kegiatan pembelajaran berlangsung. Metode observasi digunakan untuk mengamati aktivitas guru dan siswa yang dilakukan oleh pengamat atau observer.

Hasil kemampuan pemecahan masalah dinilai melalui tes evaluasi dengan persamaan berikut:

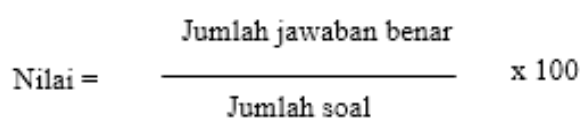


Nilai rata-rata kelas

$$
\bar{x}=\frac{\sum x}{N}
$$

Keterangan :

$x=$ nilai rata-rata kelas

$\Sigma x=$ jumlah seluruh skor

$N=$ banyaknya siswa (Arikunto, 2006:48)

Untuk mengetahui ketuntasan belajar siswa digunakan rumus:

$$
K B=\frac{T}{T t} \times 100 \%
$$

\section{Keterangan:}

$K B$ : Ketuntasan belajar

$T$ : Jumlah siswa yang tuntas belajar

$T t$ : Jumlah seluruh siswa

Tabel 1. Kiteria ketuntasan belajar siswa

\begin{tabular}{cc}
\hline Interval Skor & Kategori \\
\hline Nilai $\leq 80$ & siswa tidak tuntas belajar \\
Nilai $\geq 80$ & siswa tuntas belajar \\
\hline
\end{tabular}

\section{HaSil dan PEMbahasan}

Pada evaluasi siklus I ini siswa diberi soal postest secara tertulis dan jenis soal adalah pilihan ganda sebanyak 25 soal pilihan ganda. Hasil nilai pada siklus I dapat dilihat pada tabel dibawah ini.

Tabel 2. Kemampuan memecahkan masalah siklus I

\begin{tabular}{lc}
\hline \multicolumn{1}{c}{$\begin{array}{c}\text { Deskripsi kemampuan } \\
\text { pemecahan masalah siswa }\end{array}$} & Siklus I \\
\hline Nilai rata-rata & 74 \\
Nilai maksimal & 88 \\
Nilai minimal & 60 \\
Jumlah siswa yang tuntas & 20 \\
Jumlah siswa yang tidak & 16 \\
tuntas & \\
$\begin{array}{l}\text { Persentase ketuntasan belajar } \\
\text { Persentase ketidaktuntasan } \\
\text { belajar }\end{array}$ & $55 \%$ \\
\hline
\end{tabular}


Dari hasil tersebut diperoleh persentase ketuntasan belajar IPA sebesar 89\%, hal ini sudah sesuai dengan taraf ketuntasan belajar yaitu $>85 \%$. Nilai rata-rata siswa pada siklus II sudah mengalami peningkatan dan di atas KKM yaitu sebesar 78. Ini menandakan bahwa model pembelajaran PBL dapat mengatasi siswa dalam memecahkan masalah fisika dengan baik.

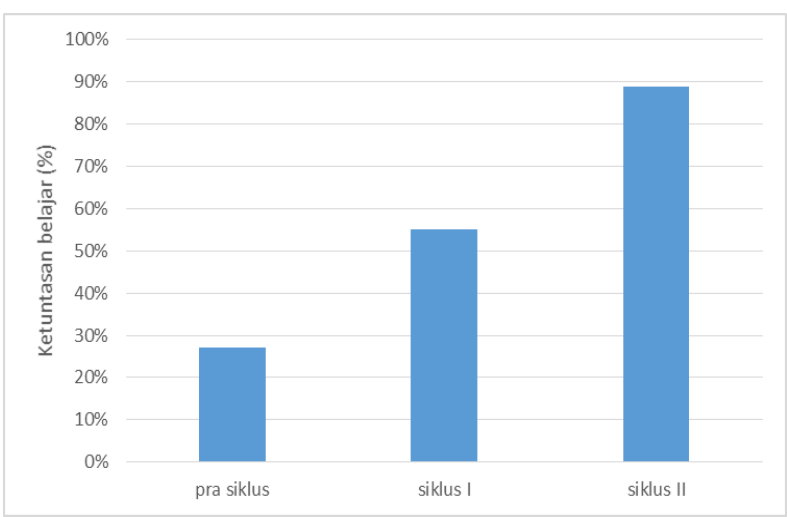

Gambar 2. Persentase ketuntasan belajar kemampuan pemecahan masalah siswa

Dari gambar 2, menunjukkan bahwa pemahaman konsep kelistrikan siswa mengalami peningkatan yang signifikan dari sebelum tindakan sampai dilakukan tindakan penelitian pada siklus II. Hal tersebut dibuktikan dengan persentase ketuntasan belajar siswa yaitu sebelum diberi tindakan ke siklus 1 terjadi peningkatan 28\%, peningkatan dari siklus I ke siklus II sebesar $34 \%$, dan peningkatan dari pra siklus sampai ke siklus II sebesar $62 \%$.

Berdasarkan analisis data perbandingan antarsiklus dapat diketahui bahwa penggunaan model pembelajaran PBL dapat meningkatkan kemampuan pemecahan masalah siswa kelas IXG MTs Negeri Magelang pada materi listrik dinamis. Siswa sudah bisa memecahkan masalah fisika secara bertahap dan dapat diaplikasikan ke dalam kehidupan sehari-hari.

\section{KESIMPULAN}

Berdasarkan hasil dan pembahasan pada penelitian tindakan kelas (PTK) yang telah diuraikan, maka dapat diperoleh kesimpulan bahwa model pembelajaran PBL dapat meningkatkan kemampuan pemecahan masalah kelistrikan pada siswa kelas IX-G MTs Negeri Magelang. Hal tersebut dibuktikan dengan persentase ketuntasan belajar siswa yaitu sebelum diberi tindakan ke siklus 1 terjadi peningkatan $28 \%$, peningkatan dari siklus I ke siklus II sebesar $34 \%$, dan peningkatan dari pra siklus sampai ke siklus II sebesar $62 \%$.

\section{Daftar Pustaka}

Arikunto, Suharsimi. 2006. Prosedur Penelitian Suatu Pendekatan Praktek. Jakarta : Rineka Cipta.

Branca, N.A. 1980. Problem Solving as Goal, Process and Basic Skills. in S Krulik and R.E. Reys (Eds). Problem Solving in School Mathematics. Washington DC: NCTM.

Huda, Miftahul. 2015. Model-model Pengajaran dan Pembelajaran. Yogyakarta: Pustaka Pelajar.

Medriati, Rosane. 2013. Upaya Peningkatan Hasil Belajar Fisika Siswa Pada Konsep Cahaya Kelas VII6 Melalui Penerapan Model Pembelajaran Problem Based Learning (PBL) Berbasis Laboratorium di SMPN 14 Kota Bengkulu. Prosiding Semirata FMIPA Universitas Lampung 2013.

Warso, Agus Wasisto Dwi Doso. 2013. Publikasi Ilmiah Penelitian Tindakan Kelas. Yogyakarta: Graha Cendekia. 